\title{
Organic Material Soil Amendment Effects on Root Rot and Sugarcane Growth and Characterization of the Materials
}

\author{
N. Dissanayake and J. W. Hoy, Department of Plant Pathology and Crop Physiology, Louisiana Agricultural Ex- \\ periment Station, Louisiana State University Agricultural Center, Baton Rouge 70803
}

\begin{abstract}
Dissanayake, N., and Hoy, J. W. 1999. Organic material soil amendment effects on root rot and sugarcane growth and characterization of the materials. Plant Dis. 83:1039-1046.

Soil amendment with different organic materials was evaluated in greenhouse experiments for effects on root rot and growth of sugarcane. Materials included composts prepared from cotton gin trash, cottonwood bark, mixed hardwood bark, municipal solid waste, and municipal yard waste; municipal biosolids; and a sugar mill by-product, filterpress cake. Field soil, steamtreated field soil, and steam-treated soil infested with Pythium arrhenomanes were amended with nonsterile or steam-treated organic materials. A metalaxyl fungicide treatment was included for comparison. When added in nonsterile form, cotton gin trash compost, filterpress cake, and biosolids suppressed disease and increased plant growth in field soil and soil infested with $P$. arrhenomanes, but this ability was reduced after steam treatment. Bark composts were capable of suppressing root rot and increasing plant growth in field soil and Pythium-infested soil when added in either nonsterile or steam-treated forms. Plant growth in steam-treated soil was not promoted by nonsterile or steam-treated materials. Disease suppression provided by organic materials resulted in plant growth increases generally lower than those resulting from metalaxyl treatment in steam-treated soil infested with $P$. arrhenomanes, but some amendments resulted in growth increases comparable to those obtained with the metalaxyl treatment in field soil. Municipal waste composts had no effect or were detrimental to sugarcane growth. Differences in microbial community composition and chemical properties, including $\mathrm{N}$ content, $\mathrm{C}: \mathrm{N}$ ratio, and other mineral nutrient levels, distinguished organic materials that may suppress disease and promote plant growth by different mechanisms. Microbial activity level of a material was an indicator of potential for disease suppression. The study results suggest that the severity of root rot in sugarcane may be reduced by amending soil with some organic materials.
\end{abstract}

Sugarcane (interspecific-hybrids of Saccharum) is an important crop in tropical and some subtropical regions of the world. It is vegetatively propagated, and multiple annual cuttings of stalks are usually harvested from a single planting. The ratoon or stubble crops develop from buds on the basal portion of plants left in the soil after harvest. In the tropics, up to 20 ratoon crops may be obtained from one planting (2). In Louisiana, however, the crop cycle is typically limited to three crops, the plant cane (first year) crop and two ratoon crops, due to a complex problem now known as stubble decline $(20,32,33)$.

Stubble decline, characterized by progressive reductions of yield in successive crops, is a major constraint to productivity and profitability of the sugarcane industry in Louisiana. Factors associated with stub-

Corresponding author: J. W. Hoy

E-mail: jhoy@agctr.lsu.edu

Approved for publication by the Director of the Louisiana Agricultural Experiment Station as manuscript 99-38-0278.

Accepted for publication 3 August 1999.

Publication no. D-1999-0921-01R

(C) 1999 The American Phytopathological Society ble decline include: host genotype, low winter temperatures and freezes, poor soil aeration and drainage, weed competition, and physiological maturity and health of the cane plant affected by growing conditions and diseases $(5,20,32,51)$.

Pythium root rot, caused by Pythium arrhenomanes, contributes to stubble decline $(21,32,33,51)$. Control of root rot would result in yield increases within the current crop cycle and could allow one or more additional ratoons to be obtained. Extending the crop cycle would increase profitability, enhance land use efficiency, and reduce soil erosion. Various methods for Pythium root rot management, such as planting of cultivars with genetic resistance $(37,56)$, use of fungicides $(14,33)$, soil solarization (52), improving drainage (5), and soil fumigation $(14,33)$ have met with limited success. Therefore, alternative means of disease management are needed.

Earlier studies identified microorganisms antagonistic to $P$. arrhenomanes in soils $(9,10,41)$. Furthermore, biological control of root rot with antagonistic actinomycetes was demonstrated in plants grown in sterile soil amended with $P$. arrhenomanes inoculum (35). In India, field resistance and susceptibility shown by two different sugarcane cultivars were associated with differences in the compo- sition of the rhizosphere microflora in the field (55).

Composted organic materials have been used with varying success for suppression of Pythium diseases of several other crops $(7,11,15,22,26,27,42,48,57,59)$. Most of these studies involved soilless container media amended with composts prepared from tree bark. Amendment of soil with composted municipal sewage sludge suppressed Pythium damping-off in cucumber and cotton $(39,42)$.

The evidence from other cropping systems suggests that soil amendment with organic materials might suppress Pythium root rot in sugarcane. However, the effects of organic material amendments on soilborne diseases appear to vary depending on many factors, such as the origin and process by which the materials are produced, the nature of the pathogen and plant, and environmental factors $(7,29,30,31,39,48,57)$. The present investigation was undertaken to study the effects of soil amendment with different organic materials on Pythium root rot and growth of sugarcane. In addition, biological and chemical properties of organic materials and field soil were determined and compared. Preliminary results have been reported (18).

\section{MATERIALS AND METHODS}

Soils and organic materials. For all experiments, soil collected from a field with a history of sugarcane cultivation was sieved through a 1-cm mesh screen, mixed with steam-treated sand to a final soil:sand ratio of $2: 1$ ( $\mathrm{vol} / \mathrm{vol})$, and divided into three parts. A portion was left unchanged and will be referred to as field soil (FS). A second portion was steam-treated for $24 \mathrm{~h}$ in $50 \times 70 \times 8 \mathrm{~cm}$ metal trays and will be referred to as steam-treated field soil (SFS). The final portion was steam-treated and then infested with $P$. arrhenomanes inoculum and will be referred to as $P$. $a r$ rhenomanes-infested SFS (SFS+Pa). The inoculum was prepared and added to soil as described previously (32).

Organic materials used as soil amendments included composts derived from municipal solid waste, municipal yard waste, cotton gin trash, and tree barks; municipal biosolids; and a sugar mill byproduct, filterpress cake. Biosolids and filterpress cake were added to soil at a rate of $10 \%(\mathrm{vol} / \mathrm{vol})$, and composts were added at a rate of $20 \%(\mathrm{vol} / \mathrm{vol})$. Organic materials were added in two different 
forms, nonsterile and steam-treated. The organic materials were steam-treated in the same way as field soil. Four greenhouse experiments were conducted using the different organic materials as soil amendments. Each material was included in at least two experiments.

The municipal biosolids were obtained from a waste-water treatment facility at La Place, Louisiana. The biosolids were treated by aeration, clarification, and anaerobic digestion. The material was then partially air-dried on clay tile beds to contain 15 to $20 \%$ solids.

The municipal solid waste compost was prepared by the Bedminster process and provided by Bioconversion, Inc., Sevierville, Tennessee. Municipal solid waste was sorted to remove inorganic, noncompostable materials. It was then combined with municipal biosolids at a ratio of $2: 1$, solid waste:biosolids ( $\mathrm{vol} / \mathrm{vol})$ and composted over a 3-day period with rapid turning. Moisture and temperature were maintained at approximately $55 \%$ and $160^{\circ} \mathrm{C}$, respectively.

Municipal yard waste compost was provided by a municipal yard waste composting facility at Lafayette, Louisiana. Yard waste was ground, amended with fertilizer, and windrowed with turning until the composting process was determined to be complete (ambient temperatures were reached).

The cotton gin trash and bark composts were provided by the Louisiana Cooperative Extension Service composting facility. Gin trash consisted of the residue of cotton ginning: leaves, stems, broken seeds, bolls, and soil. Cotton gin trash was windrowed and turned weekly for approximately 4 months. The moisture level was maintained at 40 to $55 \%$ by adding water. Temperature was recorded weekly, and the material was placed in piles when it reached ambient temperature.

Cottonwood bark compost was prepared from a volumetric mixture of $70 \%$ cottonwood (Populus deltoides) and 30\% pine (Pinus spp.) bark obtained from the James River Mill in St. Francisville, Louisiana. Fresh barks were obtained and stored in large piles for approximately 2 months until processing. The cottonwood bark was ground using a tub grinder with $10 \times 6 \mathrm{~cm}$ rectangular progressive screens. The pine bark was already ground to a particle size of $2 \mathrm{~cm}$ or less when delivered. Fertilizer was added at the rate of $225 \mathrm{~kg}$ of ammonium sulfate and $90 \mathrm{~kg}$ of phosphate per 65 $\mathrm{m}^{3}$ of bark. The fertilizer was broadcast over the surface of the windrow and incorporated with a windrow turner. Moisture level was estimated at $40 \%$ on a total weight basis, and during the composting process, water was added to maintain a 50 to $55 \%$ moisture content on a total weight basis. The windrows were turned weekly for about 13 weeks, and the material was then placed in large piles to stabilize. Bark composts were used in experiments 1 to 2 months later. Mixed hardwood bark compost was prepared with a mixture of barks from oak (Quercus spp.), sweet gum (Liquidambar styraciflua), and cottonwood obtained from the Georgia-Pacific Paper Mill in Port Hudson, Louisiana. The barks were stored in large piles for approximately 2 months until processing. The bark was ground with a tub grinder using $5 \times 10$ $\mathrm{cm}$ rectangular screens. Ammonium sulfate $(185 \mathrm{~kg})$ and $65 \mathrm{~kg}$ of phosphate were added per $55 \mathrm{~m}^{3}$ of bark. Windrows were turned as with cottonwood bark, and the final product was placed in large piles for stabilization. The temperature was monitored in both bark composts at different depths, and composting was complete when the temperature dropped to ambient level.

Sugar mill filterpress cake is a by-product of the sugarcane milling process. After cane juice is extracted, the juice is clarified by the addition of lime and heating. Soil and flocculated protein settle to the bottom of a holding tank from which it is pumped and collected on a filter. The sediment contains 2 to $3 \%$ sucrose. Filterpress cake is placed in piles outside mills during the milling period from October to December. The material used in the soil amendment experiments was collected after 3 to 6 months of natural decomposition.

Plants and experimental design. Sugarcane plants were raised from single-bud cuttings of cultivar CP 70-321, and 3week-old plants were transplanted into 15$\mathrm{cm}$-diameter clay pots filled with FS, SFS, or SFS+Pa with or without amendment with an organic material. There were five replicate plants per treatment. Plants were watered daily to keep soil moisture levels near field capacity, and they were fertilized every 2 weeks with a water soluble fertilizer mixture (N-P-K/20-20-20).

The effects of amendments on plant growth and root rot severity were evaluated after 8 weeks. All plants were removed from pots, and the root system of each was gently washed free of soil. Assessments were then taken, including total shoot number per plant, total shoot dry weight, and root system fresh weight. In addition, the root system of each plant was evaluated by subjective visual rating for rot severity assessed as amount of discoloration and reduction in the lateral root system compared with control plants grown in steam-treated field soil. Ratings were made on a scale of 1 to 4 in which $1=$ normal appearance: no discoloration or reduction of lateral root system; 1.5 = very mild root rot: up to $10 \%$ discoloration or reduction in lateral roots; $2=$ mild root rot: $>10$ to $25 \%$ of root system discolored or reduction in lateral roots; $2.5=$ moderate root rot: $>25$ to $50 \%$ of root system with root rot symptoms or lateral root system reduction; $3=$ severe root rot: $>50$ to $75 \%$ of root system discolored or reduction in lateral roots; 3.5 $=$ very severe root rot: $>75$ to $90 \%$ of root system discolored or reduction in lateral roots; and $4=$ completely rotted: $>90 \%$ of the root system discolored or with no lateral roots due to root rot. Percent root length colonized by Pythium was determined by plating six randomly selected, 5$\mathrm{cm}$ lengths of root per replicate plant (150 $\mathrm{cm}$ of root per treatment). Three root pieces were placed in a 9-cm-diameter petri dish, and PVPS modified Pythiumselective medium (47) (10 g each of corn meal agar and agar, autoclaved in 1 liter of distilled water, amended after cooling to $45^{\circ} \mathrm{C}$ with $300 \mathrm{mg}$ of vancomycin dissolved in $10 \mathrm{ml}$ of sterile water, $15 \mathrm{mg}$ of pentachloronitrobenzene dissolved in $3 \mathrm{ml}$ of $95 \% \mathrm{EtOH}, 0.4 \mathrm{ml}$ of pimaricin [10 mg a.i.], and $300 \mathrm{mg}$ of spectinomycin dissolved in $10 \mathrm{ml}$ of sterile water) was poured over the roots until they were immersed. Plates were then incubated at room temperature.

The length of root segments from which Pythium mycelium was growing into the agar was determined between 24 and $32 \mathrm{~h}$ after plating. A subset of six Pythium isolates from each plate was then transferred to V8 media plates $(200 \mathrm{ml}$ of V8 vegetable juice cocktail, $800 \mathrm{ml}$ of distilled water, $15 \mathrm{~g}$ of agar, $1 \mathrm{~g}$ of $\mathrm{CaCO}_{3}, \mathrm{pH} 4.8$, autoclaved, and amended after cooling to $45^{\circ} \mathrm{C}$ with $300 \mathrm{mg}$ of penicillin per liter). After a 24- to 48-h period of growth, six to eight agar plugs, $3 \mathrm{~mm}$ diameter, containing actively growing mycelium were transferred into a 5.5 -cm-diameter petri dish and flooded with $5 \mathrm{ml}$ of filter-sterilized soil extract. After 2 to 3 days at room temperature, identification of $P$. arrhenomanes isolates was done by microscopic examination of reproductive structures (62).

The effects of nonsterile and steamtreated organic material amendments were determined for each of the three soil mix types. Individual organic material treatments were compared to each of two controls: plants grown in unamended FS and in unamended FS with the fungicide metalaxyl (Ridomil 2E, Novartis, Greensboro, NC) applied at a rate of $0.93 \mathrm{~kg}$ a.i./ha at the beginning of the experiment. Comparisons were made within FS to determine the effects of amendment with materials on root rot severity and plant growth in the presence of the natural sugarcane soil microbial community. Within SFS, the effects of materials on plant growth were compared in the absence of the soil microbial community. The effects of materials on Pythium root rot and plant growth were then determined in $\mathrm{SFS}+\mathrm{Pa}$ when $P$. arrhenomanes was present without the rest of the microbial community. The effects of root rot and metalaxyl treatment were each determined for plant growth parameters and root rot severity across all three soil mix types: FS, SFS, and $\mathrm{SFS}+\mathrm{Pa}$.

Total bacteria and actinomycete populations. Populations of heterotrophic 
bacteria were enumerated using a soil dilution plate technique (45) involving inoculation of replicate plates containing tryptic soy agar with various 10 -fold soil dilutions. Plates were counted after 5 days $\left(25^{\circ} \mathrm{C}\right.$ in dark). Actinomyces populations were estimated by a soil dilution plate technique where the number of $\mathrm{CFU}$ was counted after incubation (14 days at $25^{\circ} \mathrm{C}$ in dark) of spread plates containing Actinomyces isolation agar (12) amended with $50 \mathrm{mg}$ of cycloheximide and $5 \mathrm{mg}$ of polymyxin B per liter.

Chemical properties of soil and organic materials. Chemical characteristics (pH; organic C, total $\mathrm{N}$; C:N; extractable $\mathrm{P}$, $\mathrm{K}, \mathrm{Ca}, \mathrm{Mg}, \mathrm{Mn}$, and $\mathrm{S}$; and salts) of the soil (Commerce silt loam: silty, mixed, nonacid, thermic Aeric Fluvaquents) and of each organic material were determined from two samples by the Louisiana Agricultural Experiment Station soil testing lab (19). The amount of heavy metals (As, Cd, $\mathrm{Cu}, \mathrm{Fe}, \mathrm{Mn}, \mathrm{Ni}, \mathrm{Pb}$, and $\mathrm{Zn}$ ) available to plants and microorganisms was estimated by extracting two $10 \mathrm{-g}$ samples of soil or organic material-amended soil with diethylenetriaminepentaacetate acid-triethanolamine (40).

Determination of microbial activity. The heterotrophic microbial activity of the various organic materials and field soil was investigated by measuring the rate at which fluorescein diacetate (FDA) was hydrolyzed (54). Fifty $\mathrm{ml}$ of $60 \mathrm{mM}$ phosphate buffer ( $\mathrm{pH} 7.6$ ) and $0.5 \mathrm{ml}$ of FDA (2 g per liter) were added to a 250-ml Erlenmeyer flask containing a 2 -g wet sample. The flasks were stoppered and incubated for 60 min at $25^{\circ} \mathrm{C}$ on a rotary shaker $(200 \mathrm{rpm})$; $50 \mathrm{ml}$ of acetone was added, and the flask was swirled to stop further microbial ac- tivity. A 30-ml aliquot was centrifuged $(3,000 \times g ; 5 \mathrm{~min})$ and clarified using a disposable syringe filter $(0.45 \mu \mathrm{m})$. Absorbance was then measured at $490 \mathrm{~nm}$. The rate of FDA hydrolysis was calculated by adjusting for water content and using a standard curve prepared by adding increasing known amounts of fluorescein to extracts obtained after adding $50 \mathrm{ml}$ of buffer and $50 \mathrm{ml}$ of acetone to materials or soil, shaking for $60 \mathrm{~min}$, and filtering. Each treatment was replicated three times.

Statistical analyses. A completely randomized design was used in all greenhouse experiments. Root rot severity ratings were converted to the percentage midpoint for the appropriate interval and then transformed to arcsine values before statistical analysis. Data for percent root length colonized by $P$. arrhenomanes also were transformed to arcsine values before analysis. Data for treatments within FS, SFS, and $\mathrm{SFS}+\mathrm{Pa}$ were subjected to analysis of variance for individual and combined experiments. The results of the combined analyses are presented. Individual experiment results have been reported previously (17). Differences between organic material treatment means and respective control treatments within each soil mix type (FS, $\mathrm{SFS}$, and $\mathrm{SFS}+\mathrm{Pa}$ ) were determined using Dunnett's least significant difference test at the $5 \%$ level of probability. Data for the unamended FS, SFS, and SFS+Pa treatments with and without metalaxyl were subjected to analysis of variance, then compared with each other using Fisher's protected least significant difference test at the $5 \%$ level of probability.

Differences between means for microbial activity and total bacteria and actinomycete populations were determined using
Duncan's new multiple range test at the 5\% level of probability. Microbial activity levels and chemical characteristics for soil and the organic materials were tested for correlation with means for plant growth parameters and root rot symptom severity by Pearsons correlation analysis. Comparisons of nutrient analysis results for field soil and organic materials were made using Fisher's protected least significant difference test at the 5\% level of probability. All statistical analyses were performed using the Statistical Analysis System, Version 6.2 (SAS Institute, Cary, NC).

\section{RESULTS}

Effects of root rot and metalaxyl treatment on plant growth. Plants grown in FS had reduced root and shoot weight and shoot number (Table 1), in association with moderate root rot severity (Table 2), compared with plants grown in SFS (outcomes of analyses comparing FS, SFS, and SFS+Pa not shown). Plants grown in $\mathrm{SFS}+\mathrm{Pa}$ exhibited further reductions in growth and an increase in disease severity compared with those grown in FS (Tables 1 and 2). Metalaxyl treatment increased all growth parameters for plants in SFS+Pa to levels equivalent with plants in SFS (Table 1), and Pythium infection and disease symptoms were alleviated (Table 2). In FS, shoot number was similar but root and shoot weight were lower for metalaxyl-treated plants compared with SFS (Table 1), and Pythium infection and disease symptoms were still evident for treated plants (Table 2). However, metalaxyl increased all plant growth parameters and reduced disease severity and Pythium colonization in both FS and $\mathrm{SFS}+\mathrm{Pa}$.

Table 1. Effects of soil amendment with organic materials on sugarcane growth in field soil (FS), steam-treated field soil (SFS), and steam-treated field soil infested with Pythium arrhenomanes (SFS $+\mathrm{Pa}$ )

\begin{tabular}{|c|c|c|c|c|c|c|c|c|c|c|}
\hline \multirow[b]{3}{*}{ Treatment $^{\mathrm{y}}$} & \multirow[b]{3}{*}{ Form $^{\mathrm{z}}$} & \multicolumn{9}{|c|}{ Plant growth parameter } \\
\hline & & \multicolumn{3}{|c|}{ Root fresh wt. (g) } & \multicolumn{3}{|c|}{ Shoot dry wt. (g) } & \multicolumn{3}{|c|}{ Shoot number } \\
\hline & & FS & $\mathrm{SFS}+\mathrm{Pa}$ & SFS & FS & $\mathrm{SFS}+\mathrm{Pa}$ & SFS & FS & $\mathrm{SFS}+\boldsymbol{P a}$ & SFS \\
\hline No amendment & & $\dagger 14.9$ & $\dagger 10.4$ & 26.3 & $\dagger 8.5$ & $\dagger 5.4$ & 13.9 & $\dagger 2.8$ & $\dagger 2.1$ & 5.0 \\
\hline Metalaxyl & & $19.2 *$ & $23.4^{*}$ & 22.6 & $12.0^{*}$ & $13.9^{*}$ & 13.6 & $4.0^{*}$ & $4.6^{*}$ & 5.6 \\
\hline $\begin{array}{l}\text { Cotton gin } \\
\text { trash compost }\end{array}$ & $\begin{array}{l}\mathrm{N} \\
\mathrm{S}\end{array}$ & $\begin{array}{c}\dagger 23.6^{*} \\
18.3\end{array}$ & $\begin{array}{r}\dagger 13.4 \\
\dagger 8.5\end{array}$ & $\begin{array}{l}24.3 \\
22.5\end{array}$ & $\begin{array}{l}13.2^{*} \\
\dagger 9.7\end{array}$ & $\begin{array}{l}\dagger 7.9^{*} \\
\dagger 4.5\end{array}$ & $\begin{array}{l}12.6 \\
12.2\end{array}$ & $\begin{array}{r}\dagger 5.0^{*} \\
3.9^{*}\end{array}$ & $\begin{array}{l}\dagger 3.1^{*} \\
\dagger 1.7\end{array}$ & $\begin{array}{l}3.9^{*} \\
3.7^{*}\end{array}$ \\
\hline $\begin{array}{l}\text { Cottonwood } \\
\text { bark compost }\end{array}$ & $\begin{array}{l}\mathrm{N} \\
\mathrm{S}\end{array}$ & $\begin{array}{l}\dagger 27.1 * \\
\dagger 25.9 *\end{array}$ & $\begin{array}{l}\dagger 18.1^{*} \\
\dagger 15.7^{*}\end{array}$ & $\begin{array}{l}\dagger 32.6 \\
\dagger 32.5\end{array}$ & $\begin{array}{l}13.3^{*} \\
12.7^{*}\end{array}$ & $\begin{array}{l}\dagger 6.4 \\
\dagger 6.7\end{array}$ & $\begin{array}{l}14.5 \\
16.3\end{array}$ & $\begin{array}{l}3.3 \\
3.4\end{array}$ & $\begin{array}{l}\dagger 2.5 \\
\dagger 2.2\end{array}$ & $\begin{array}{l}4.3 \\
4.9\end{array}$ \\
\hline $\begin{array}{l}\text { Hardwood } \\
\text { bark compost }\end{array}$ & $\begin{array}{l}\mathrm{N} \\
\mathrm{S}\end{array}$ & $\begin{array}{c}19.1 \\
\dagger 25.3^{*}\end{array}$ & $\begin{array}{l}\dagger 13.6 \\
\dagger 13.8\end{array}$ & $\begin{array}{l}\dagger 34.5^{*} \\
\dagger 31.8\end{array}$ & $\begin{array}{l}10.9^{*} \\
13.1^{*}\end{array}$ & $\begin{array}{l}\dagger 6.2 \\
\dagger 6.2\end{array}$ & $\begin{array}{c}15.4 \\
\dagger 16.9^{*}\end{array}$ & $\begin{array}{l}3.7 \\
3.6\end{array}$ & $\begin{array}{l}\dagger 1.6 \\
\dagger 1.9\end{array}$ & $\begin{array}{l}4.0 \\
4.8\end{array}$ \\
\hline $\begin{array}{r}\text { Municipal } \\
\text { biosolids }\end{array}$ & $\begin{array}{l}\mathrm{N} \\
\mathrm{S}\end{array}$ & $\begin{array}{r}16.0 \\
\dagger 11.4\end{array}$ & $\begin{array}{r}\dagger 13.5 \\
\dagger 6.2\end{array}$ & $\begin{array}{l}22.0 \\
24.4\end{array}$ & $\begin{array}{c}8.2 \\
\dagger 6.1^{*}\end{array}$ & $\begin{array}{l}\dagger 9.1^{*} \\
\dagger 3.4\end{array}$ & $\begin{array}{l}14.7 \\
13.0\end{array}$ & $\begin{array}{l}4.0^{*} \\
\dagger 2.3\end{array}$ & $\begin{array}{l}4.0^{*} \\
\dagger 1.5\end{array}$ & $\begin{array}{c}5.6 \\
+6.7^{*}\end{array}$ \\
\hline $\begin{array}{l}\text { Municipal solid } \\
\text { waste compost }\end{array}$ & $\begin{array}{l}\mathrm{N} \\
\mathrm{S}\end{array}$ & $\begin{array}{l}\dagger 13.1 \\
\dagger 10.8\end{array}$ & $\begin{array}{l}\dagger 6.6 \\
\dagger 6.0^{*}\end{array}$ & $\begin{array}{r}\dagger 9.3^{*} \\
\dagger 14.2^{*}\end{array}$ & $\begin{array}{l}\dagger 6.9 \\
\dagger 6.1 *\end{array}$ & $\begin{array}{l}\dagger 4.5 \\
\dagger 3.8\end{array}$ & $\begin{array}{l}\dagger 6.0^{*} \\
\dagger 8.1^{*}\end{array}$ & $\begin{array}{l}\dagger 1.5^{*} \\
\dagger 1.6^{*}\end{array}$ & $\begin{array}{l}\dagger 1.3 \\
\dagger 1.0^{*}\end{array}$ & $\begin{array}{l}\dagger 2.1^{*} \\
\dagger 1.5^{*}\end{array}$ \\
\hline $\begin{array}{l}\text { Municipal yard } \\
\text { waste compost }\end{array}$ & $\begin{array}{l}\mathrm{N} \\
\mathrm{S}\end{array}$ & $\begin{array}{r}17.2 \\
\dagger 10.5\end{array}$ & $\begin{array}{l}\dagger 7.3 \\
\dagger 5.7\end{array}$ & $\begin{array}{l}21.1 \\
18.2 *\end{array}$ & $\begin{array}{l}\dagger 8.8 \\
\dagger 6.1 *\end{array}$ & $\begin{array}{l}\dagger 3.7 \\
\dagger 3.0 *\end{array}$ & $\begin{array}{l}11.5 \\
\dagger 10.2^{*}\end{array}$ & $\begin{array}{l}3.6 \\
3.2\end{array}$ & $\begin{array}{l}\dagger 2.2 \\
\dagger 1.1^{*}\end{array}$ & $\begin{array}{l}5.1 \\
4.8\end{array}$ \\
\hline $\begin{array}{l}\text { Sugar mill } \\
\text { filterpress cake }\end{array}$ & $\begin{array}{l}\mathrm{N} \\
\mathrm{S}\end{array}$ & $\begin{array}{r}\dagger 24.3^{*} \\
21.4^{*}\end{array}$ & $\begin{array}{l}\dagger 18.8^{*} \\
\dagger 11.2\end{array}$ & $\begin{array}{r}\dagger 29.0 \\
27.9\end{array}$ & $\begin{array}{l}12.5^{*} \\
11.0^{*}\end{array}$ & $\begin{array}{l}\dagger 8.1 * \\
\dagger 5.7\end{array}$ & $\begin{array}{l}14.8 \\
14.2\end{array}$ & $\begin{array}{l}4.6^{*} \\
3.4\end{array}$ & $\begin{array}{l}3.8^{*} \\
\dagger 2.3\end{array}$ & $\begin{array}{l}4.6 \\
4.6\end{array}$ \\
\hline
\end{tabular}

y Each value represents a mean from multiple experiments. Values followed by * within FS, SFS, or SFS+Pa and within each growth parameter were different $(P>0.95)$ from the corresponding no amendment control mean. Values preceded by $\dagger$ within FS, SFS, and SFS $+P a$ and each growth parameter were different $(P>0.95)$ from the corresponding metalaxyl treatment mean.

${ }^{\mathrm{z}}$ Each organic material was added in nonsterile $(\mathrm{N})$ or steam-treated $(\mathrm{S})$ form. 
Effects of organic materials on plant growth. In the overall analysis, two-way interactions were significant, indicating that the effects of different organic materials were variable in the different soil mix types and when they were added in nonsterile or steam-treated forms. In field soil, amendments with nonsterile gin trash and cottonwood bark composts and filterpress cake increased root and shoot weights, and shoot number was increased by addition of gin trash compost, filterpress cake, and municipal biosolids (Table 1). Cottonwood bark compost and filterpress cake, along with hardwood bark compost, also increased root and shoot weights when added in steam-treated form. The root weight increases resulting from the addition of the two bark composts and nonsterile filterpress cake were greater than the effect of metalaxyl application (Table 1). The addition of the two municipal waste composts in steam-treated form caused some reductions in plant growth in field soil.

In steamed soil infested with $P$. arrhenomanes, filterpress cake increased all three plant growth parameters, gin trash compost and biosolids increased shoot number and weight, and cottonwood bark compost increased root weight when added in nonsterile form (Table 1). Metalaxyl increased growth more than organic material amendments in steamed-soil infested with $P$. arrhenomanes. Municipal solid and yard waste composts sometimes reduced growth when added in nonsterile form.

The only increase in growth observed in steam-treated soil resulted from the addition of hardwood bark compost, which increased root weight when added in nonsterile form, and hardwood bark and biosolids, which increased shoot weight and number, respectively, when added in steam-treated form (Table 1). Municipal solid waste compost decreased plant growth when added in nonsterile or steamtreated forms, and yard waste compost decreased root and shoot weight when added in steam-treated form.

Effects of organic materials on root rot. In field soil, gin trash and cottonwood bark composts reduced the severity of root rot when they were added in nonsterile and steam-treated forms, and amendment with nonsterile hardwood bark compost, biosolids, and filterpress cake reduced root rot severity (Table 2). Addition of each of these materials, except nonsterile gin trash compost, resulted in comparable reductions in rot severity to the metalaxyl treatment (Table 2). The same materials reduced rot severity in steamed soil infested with $P$. arrhenomanes only when added in nonsterile form, but metalaxyl provided a greater reduction in rot severity. Municipal solid and yard waste composts in both nonsterile and steam-treated forms adversely affected root system development in steamed field soil (Table 2).

Organic material amendments had fewer effects on root colonization by $P$. arrhenomanes (Table 2). Colonization was lower in field soil than in steamed soil infested with $P$. arrhenomanes, and only nonsterile hardwood bark and yard waste composts and steam-treated biosolids reduced percent colonization. The colonization levels for steam-treated biosolids and nonsterile yard waste compost were comparable to the metalaxyl treatment. In Pythium-infested steamed soil, nonsterile biosolids and filterpress cake and both nonsterile and steam-treated municipal solid and yard waste composts reduced colonization. The metalaxyl treatment provided greater reductions in colonization than all organic materials in steamed soil infested with $P$. arrhenomanes.

Microbial activity of organic materials. Comparisons of the capacity of microbial communities to hydrolyze FDA indicated differences in activity among the organic materials used as soil amendments (Table 3). Activity levels were higher in all materials than in the soil obtained from a sugarcane field. The highest microbial activity level was found in municipal biosolids, followed by filterpress cake. The lowest activity levels detected were for the municipal solid waste and yard waste composts. Filterpress cake and biosolids contained larger populations of total bacteria and actinomycetes than the other materials (Table 3). Among the composts, only cotton gin trash and mixed hardwood bark contained larger actinomycete populations than were found in field soil, while yard waste and cotton gin trash had higher total bacterial populations.

Chemical properties of field soil and organic materials. Organic materials contained variable but generally higher levels of plant nutrients, organic $\mathrm{C}$, and salts than did field soil (Table 4). C:N ratios were highest for the bark and solid waste composts, followed by yard waste compost (Table 4). Biosolids, filterpress cake, and gin trash compost generally contained higher concentrations of $\mathrm{N}, \mathrm{P}, \mathrm{K}$, and $\mathrm{Mg}$ than did other organic materials (Table 4). Biosolids had the highest $\mathrm{N}$ content; filterpress cake had the highest $\mathrm{P}$ and $\mathrm{Mg}$ contents; and gin trash compost

Table 2. Effects of soil amendment with organic materials on root rot of sugarcane in field soil (FS), steam-treated field soil (SFS), and steam-treated soil infested with Pythium arrhenomanes (SFS $+P a$ )

\begin{tabular}{|c|c|c|c|c|c|c|c|}
\hline \multirow[b]{2}{*}{ Amendment ${ }^{\mathrm{w}}$} & \multirow[b]{2}{*}{ Form $^{\mathrm{x}}$} & \multicolumn{3}{|c|}{$\begin{array}{l}\text { Percentage of root system } \\
\text { affected by root rot }{ }^{\mathrm{y}}\end{array}$} & \multicolumn{3}{|c|}{$\begin{array}{c}\text { Root length } \\
\text { colonized by } \mathrm{Pa}(\%)^{\mathrm{z}}\end{array}$} \\
\hline & & FS & $\mathrm{SFS}+\mathrm{Pa}$ & SFS & FS & $\mathrm{SFS}+\boldsymbol{P a}$ & SFS \\
\hline No amendment & & $\dagger 36$ & $\dagger 55$ & - & $\dagger 26$ & $\dagger 71$ & 0 \\
\hline Metalaxyl & & $17^{*}$ & $5^{*}$ & 0 & 9* & $4 *$ & 0 \\
\hline Cotton gin & $\mathrm{N}$ & $10^{*}$ & $\dagger 21 *$ & 0 & $\dagger 20$ & $\dagger 66$ & 0 \\
\hline trash compost & $\mathrm{S}$ & $\dagger 24 *$ & $\dagger 43$ & 0 & $\dagger 29$ & $\dagger 63$ & 0 \\
\hline Cottonwood & $\mathrm{N}$ & $20 *$ & $\dagger 41^{*}$ & 0 & $\dagger 22$ & $\dagger 73$ & 0 \\
\hline bark compost & $\mathrm{S}$ & $16^{*}$ & $\dagger 52$ & 0 & $\dagger 27$ & $\dagger 72$ & 0 \\
\hline Hardwood & $\mathrm{N}$ & $22^{*}$ & $\dagger 45^{*}$ & 0 & $\dagger 17^{*}$ & $\dagger 69$ & 0 \\
\hline bark compost & $\mathrm{S}$ & $\dagger 26$ & $\dagger 51$ & 0 & $\dagger 23$ & $\dagger 74$ & 0 \\
\hline Municipal & $\mathrm{N}$ & $14 *$ & $\dagger 23^{*}$ & 0 & $\dagger 20$ & $\dagger 41^{*}$ & 0 \\
\hline biosolids & $\mathrm{S}$ & $\dagger 29$ & $\dagger 56$ & 0 & $15^{*}$ & $\dagger 58$ & 0 \\
\hline Municipal solid & $\mathrm{N}$ & $\dagger 30$ & $\dagger 59$ & $\dagger 14 *$ & $\dagger 19$ & $\dagger 54^{*}$ & 0 \\
\hline waste compost & $\mathrm{S}$ & $\dagger 33$ & $\dagger 58$ & $\dagger 9 *$ & $\dagger 23$ & $\dagger 51^{*}$ & 0 \\
\hline Municipal yard & $\mathrm{N}$ & $\dagger 28$ & $\dagger 55$ & $\dagger 14 *$ & $12 *$ & $\dagger 50^{*}$ & 0 \\
\hline waste compost & $\mathrm{S}$ & $\dagger 40$ & $\dagger 40^{*}$ & $\dagger 7 *$ & $\dagger 22$ & $\dagger 56^{*}$ & 0 \\
\hline Sugar mill & $\mathrm{N}$ & $20 *$ & $\dagger 38^{*}$ & 3 & $\dagger 22$ & $\dagger 56^{*}$ & 0 \\
\hline filterpress cake & $\mathrm{S}$ & $\dagger 34$ & $\dagger 55$ & 0 & $\dagger 26$ & $\dagger 63$ & 0 \\
\hline
\end{tabular}

${ }^{\text {w}}$ Each value represents a mean from multiple experiments. Values followed by $*$ within FS, SFS, or SFS+Pa and within each growth parameter were different $(P>0.95)$ from the corresponding no amendment control mean. Values preceded by $\dagger$ within FS, SFS, and SFS $+P a$ and each growth parameter were different $(P>0.95)$ from the corresponding metalaxyl treatment mean.

${ }^{x}$ Each organic material was added in nonsterile $(\mathrm{N})$ or steam-treated $(\mathrm{S})$ form.

${ }^{y}$ Root rot percentage estimated by subjective visual rating comparing all treatments to the steamed field soil/no amendment treatment.

${ }^{\mathrm{z}}$ Percent root length colonized by Pythium arrhenomanes determined from six 5-cm root segments collected from each of five replicate plants per treatment. 
had the highest $\mathrm{K}$ content. Municipal solid waste compost contained the highest levels of organic C, salts, Mn, and S (Table 4). Analyses of organic material-amended and -nonamended soil found that changes in the levels of heavy metals were variable (Table 5). The metals increased by organic material addition were Mn (six materials), $\mathrm{Zn}$ (three materials), Fe (two materials), and $\mathrm{As}$ and $\mathrm{Pb}$ (one material). Municipal solid waste compost and biosolid amendincreases in soil metal concentrations. Biosolids-amended soil had elevated levels of $\mathrm{Cu}, \mathrm{Fe}, \mathrm{Mn}$, and $\mathrm{Zn}$, and municipal solid waste compost-amended soil had elevated levels of $\mathrm{Fe}, \mathrm{Mn}, \mathrm{Pb}$, and $\mathrm{Zn}$.

Correlation analyses. Correlation analyses indicated that root rot symptom ments resulted in the greatest number of

severity was negatively correlated with microbial activity level $(r=-0.78 ; P=$ $0.02)$, but root weight $(r=0.23 ; P=0.58)$, shoot weight $(r=0.17 ; P=0.68)$, and shoot number $(r=0.49 ; P=0.21)$ for plants grown in soils amended with different materials were not. Other variables that were correlated with microbial activity were total bacterial population $(r=0.84 ; P$ $=0.01)$, organic material Mn content $(r=$ 0.94; $P=0.0006)$, total N $(r=0.79 ; P=$ $0.02)$, and Ca content $(r=0.78 ; P=0.02)$. Three variables were correlated with total bacterial population: organic material $\mathrm{Mn}$ content $(r=0.90 ; P=0.002)$, total $\mathrm{N}(r=$ $0.87 ; P=0.005)$, and $\mathrm{Cu}$ content $(r=0.80$; $P=0.018)$. Three variables were correlated with actinomycete population: $\mathrm{P}(r=0.98$; $P=0.0001), \operatorname{Mg}(r=0.79 ; P=0.02)$, and

Table 3. Total microbial activity and total bacterial and actinomycete populations in silt loam field soil and seven organic materials

\begin{tabular}{|c|c|c|c|}
\hline Material & $\begin{array}{c}\text { Microbial } \\
\text { activity }^{\mathrm{y}}\end{array}$ & $\begin{array}{c}\text { Total bacterial } \\
\text { population }\left(\times 10^{7}\right)^{\mathrm{z}}\end{array}$ & $\begin{array}{c}\text { Actinomycete } \\
\text { population }\left(\times 10^{5}\right)^{z}\end{array}$ \\
\hline Cotton gin trash compost & $5.6 \mathrm{~cd}$ & $2.1 \mathrm{~d}$ & $3.6 \mathrm{~cd}$ \\
\hline Cottonwood bark compost & $5.2 \mathrm{~d}$ & $1.7 \mathrm{de}$ & $2.0 \mathrm{de}$ \\
\hline Field soil & $0.9 \mathrm{~g}$ & $0.9 \mathrm{e}$ & $0.4 \mathrm{e}$ \\
\hline Hardwood bark compost & $5.9 \mathrm{c}$ & $1.2 \mathrm{de}$ & $4.1 \mathrm{c}$ \\
\hline Municipal biosolids & $10.5 \mathrm{a}$ & $26.5 \mathrm{a}$ & $8.2 \mathrm{~b}$ \\
\hline Municipal solid waste compost & $4.1 \mathrm{e}$ & $1.8 \mathrm{de}$ & $1.8 \mathrm{de}$ \\
\hline Municipal yard waste compost & $3.6 \mathrm{f}$ & $2.7 \mathrm{~cd}$ & $1.9 \mathrm{de}$ \\
\hline Sugar mill filterpress cake & $7.1 \mathrm{~b}$ & $11.8 \mathrm{~b}$ & $23.2 \mathrm{a}$ \\
\hline
\end{tabular}

${ }^{y}$ Microbial activity was estimated by fluorescein diacetate (FDA) hydrolytic assay. Mean values are $\mu \mathrm{g}$ FDA hydrolized $\min ^{-1} \mathrm{~g}^{-1}$ dry matter. Means followed by the same letter were not different $(P>$ 0.05 ) as determined by Duncan's new multiple range test.

${ }^{\mathrm{z}}$ Bacterial and actinomycete population means are CFU g ${ }^{-1}$ dry matter. Means followed by the same letter within a column were not different $(P>0.05)$ as determined by Duncan's new multiple range test.
Ca content $(r=0.78 ; P=0.02)$. Three variables were correlated with total bacterial population: organic material $\mathrm{Mn}$ content $(r=0.90 ; P=0.002)$, total $\mathrm{N}(r=0.87$; $P=0.0001)$, and $\mathrm{Mg}(r=0.79 ; P=0.02)$. Chemical properties were not correlated with plant growth or disease severity.

\section{DISCUSSION}

Soil amendment with different organic materials had varied effects on root rot and sugarcane growth. Amendment of sugarcane field soil with composts prepared from three agricultural by-products, cotton gin trash, cottonwood mixed with pine bark, and mixed hardwood bark, and two additional organic materials, municipal biosolids and sugar mill filterpress cake, suppressed root rot and increased plant growth. In contrast, two municipal waste composts prepared from total solid and yard wastes did not reduce disease severity or increase sugarcane growth. Additional evidence suggested the mechanisms of disease suppression and growth enhancement varied among the different organic materials.

Steam-treatment of gin trash compost, biosolids, and filterpress cake prior to amendment resulted in reduced ability to suppress root rot and enhance plant growth. These results suggest that the microbial community associated with these organic materials was capable of suppressing disease and thereby enhancing plant growth. Loss of suppressiveness following heat treatment was the evidence suggesting a microbial nature for suppres-

Table 4. Some chemical properties of silt loam field soil and seven organic materials used as soil amendments

\begin{tabular}{|c|c|c|c|c|c|c|c|c|c|c|}
\hline \multirow[b]{2}{*}{ Material } & \multirow{2}{*}{$\begin{array}{c}\text { Organic } \\
\qquad \mathbf{C}^{\mathrm{z}}\end{array}$} & \multirow{2}{*}{$\begin{array}{c}\text { Total } \\
\mathbf{N}^{\mathrm{z}}\end{array}$} & \multirow[b]{2}{*}{$\mathrm{C}: \mathrm{N}$} & \multicolumn{7}{|c|}{ Extractable nutrients ${ }^{z}$} \\
\hline & & & & $\mathbf{P}$ & $\mathbf{K}$ & $\mathbf{C a}$ & Mg & Mn & $\mathbf{S}$ & Salt \\
\hline Cotton gin trash compost & 143 & 20 & 12 & 2,674 & 13,342 & 5,370 & 1,604 & 66 & 464 & 10,695 \\
\hline Cottonwood bark compost & 217 & 6 & 29 & 1,485 & 1,810 & 9,142 & 702 & 108 & 1,684 & 5,629 \\
\hline Field soil & 6 & 8 & 9 & 284 & 110 & 1,924 & 351 & 39 & 10 & 205 \\
\hline Hardwood bark compost & 213 & 8 & 29 & 1,083 & 1,157 & 8,056 & 430 & 160 & 1,112 & 4,895 \\
\hline Municipal biosolids & 216 & 35 & 7 & 6,250 & 1,277 & 8,766 & 1,274 & 225 & 864 & 7,801 \\
\hline Municipal solid waste compost & 352 & 13 & 27 & 2,420 & 3,948 & 6,086 & 1,135 & 319 & 2,168 & 18,971 \\
\hline Municipal yard waste compost & 138 & 7 & 16 & 527 & 2,160 & 6,034 & 757 & 59 & 90 & 2,172 \\
\hline Sugar mill filterpress cake & 143 & 15 & 11 & 15,239 & 4,609 & 9,893 & 2,153 & 135 & 214 & 7,358 \\
\hline $\operatorname{LSD}(P=0.05)$ & 39 & 3 & 3 & 3,299 & 1,080 & 3,041 & 311 & 79 & 95 & 3,441 \\
\hline
\end{tabular}

${ }^{\mathrm{z}}$ Each value represents a mean of two samples. Units for $\mathrm{C}$ and $\mathrm{N}$ are $\mathrm{g} \mathrm{kg}^{-1}$, and units for other nutrients are $\mathrm{mg} \mathrm{kg}^{-1}$ of dry matter.

Table 5. Comparison of selected metal element content of silt loam sugarcane field soil and soil amended with seven organic materials

\begin{tabular}{|c|c|c|c|c|c|c|c|c|}
\hline \multirow[b]{2}{*}{ Materialy $^{\mathbf{y}}$} & \multicolumn{8}{|c|}{ Metal element ${ }^{\mathrm{z}}$} \\
\hline & As & Cd & $\mathbf{C u}$ & $\mathbf{F e}$ & Mn & $\mathbf{N i}$ & $\mathbf{P b}$ & $\mathbf{Z n}$ \\
\hline Cotton gin trash compost & 10.0 & 0.6 & 3.2 & 70.0 & 58.5 & 4.1 & 3.1 & 8.2 \\
\hline Cottonwood bark compost & 7.6 & 0.7 & 4.3 & 104.0 & 64.5 & 3.2 & 3.9 & 11.4 \\
\hline Field soil & 4.1 & 0.6 & 4.4 & 110.5 & 30.5 & 2.9 & 2.9 & 9.5 \\
\hline Hardwood bark compost & 8.7 & 0.7 & 4.7 & 115.0 & 71.0 & 3.8 & 2.3 & 11.6 \\
\hline Municipal biosolids & 4.9 & 0.4 & 10.7 & 298.0 & 130.0 & 2.7 & 3.7 & 48.3 \\
\hline Municipal solid waste compost & 5.1 & 0.3 & 7.8 & 345.0 & 70.1 & 3.2 & 6.8 & 40.8 \\
\hline Municipal yard waste compost & 3.1 & 0.5 & 3.4 & 98.1 & 69.5 & 2.5 & 3.1 & 26.5 \\
\hline Sugar mill filterpress cake & 7.7 & 0.5 & 5.5 & 251.5 & 93.5 & 4.1 & 5.1 & 19.6 \\
\hline $\operatorname{LSD}(P=0.05)$ & 4.8 & 0.5 & 3.5 & 144.6 & 32.0 & 1.9 & 2.3 & 11.2 \\
\hline
\end{tabular}

y Municipal biosolids and filterpress cake were added at a rate of $10 \%$ (vol/vol), and composts were added at a rate of $20 \%$ (vol/vol).

${ }^{\mathrm{z}}$ Each value represents a mean of two samples. Units are $\mathrm{mg} \mathrm{kg}^{-1}$. 
sion of disease in previous research $(7,8,11,49,60)$. In this study, amendment of steam-treated soil with either nonsterile or steam-treated forms of any organic material usually did not result in increased plant growth. This provides additional evidence suggesting that disease suppression rather than physical or nutritional improvements in the amended soil was the cause of increased plant growth.

The suppression of root rot resulting from amendment with organic materials could be related to enhancement of activity by organisms antagonistic to $P$. arrhenomanes already present in field soil $(9,10,35,41)$. Amendments with nonsterile gin trash compost, cottonwood bark compost, hardwood bark compost, biosolids, and filterpress cake reduced root rot symptom severity in the absence of the natural sugarcane soil microbial community in steam-treated soil infested with $P$. arrhenomanes. In addition, steam-treated hardwood bark compost, biosolids, and filterpress cake did not reduce disease severity in nonsterile sugarcane field soil. This evidence supports the hypothesis that microbial populations present in the organic materials were capable of suppressing root rot.

Plant growth increases resulting from soil amendment with filterpress cake and biosolids have been reported previously. Field application of filterpress cake, at the rate of $20 \mathrm{t} / \mathrm{ha}$, increased cane yield $20 \%$ in plant cane and ratoon crops (38), but no reference was made to root disease control. Compost prepared from filterpress cake and bagasse suppressed damping-off of container-grown cucumber plants caused by $P$. aphanidermatum (59). Applications of municipal biosolids to corn, soybean, and wheat fields in Tennessee $(13,46)$ and biosolids compost application to onion, lettuce, and turf in California (1) have resulted in yield increases. However, the beneficial effects were attributed to improvements in soil nutrition and soil moisture holding capacity. Application of composted municipal biosolids increased soil microbial activity and suppressed root diseases caused by Pythium and Rhizoctonia $(39,42)$. In another study, field application of biosolids enhanced soil microbial biomass and microbial activity (23). Results from a preliminary field experiment, in which sugarcane plants were transplanted into soil amended with organic wastes, found that amendments with biosolids, filterpress cake, and gin trash compost suppressed root rot and increased plant growth (17). The first large-scale application of biosolids to sugarcane resulted in yield increases in two cultivars (4). However, the results from subsequent experiments have been erratic (unpublished data).

Cottonwood and pine bark compost, mixed hardwood bark compost, and filterpress cake increased plant growth in sugarcane field soil amended with steam-treated compost, and steam-treated cottonwood bark and gin trash composts reduced disease symptom severity in field soil. These effects could be due to either the enhancement of naturally occurring biological control or abiotic factors associated with the organic materials. The presence of toxic compounds inhibitory to Phytophthora has been documented in recently produced bark composts $(6,31)$. This possible combination of biotic and abiotic factors affecting disease and plant growth is similar to the postulated effects of waste amendments on Pythium in turf (48).

The municipal solid waste and yard waste composts used in this study reduced colonization by $P$. arrhenomanes when added in nonsterile or steam-treated form, but they did not increase plant growth. Instead, occasional detrimental effects on plant growth were observed in all three soil mix types following amendment with steam-treated or nonsterile composts. In addition, plants grown in steam-treated soil amended with either nonsterile or steamtreated composts exhibited root damage symptoms. These results suggest that toxic materials were present. In multiple year field experiments, amendment with the same municipal waste compost increased sugarcane yields in some cases (28). The municipal solid waste compost used in this study was prepared by a rapid composting process at very high temperature. Composts prepared at high temperatures (in excess of $60^{\circ} \mathrm{C}$ ) were not suppressive to diseases caused by different pathogens, including Pythium $(7,8,44,57)$. After exposure to lower temperatures, disease-conducive composts became suppressive. $\mathrm{Mu}-$ nicipal solid waste compost amendments have provided beneficial improvements to soil physical, chemical, and biological properties in other field studies $(24,25,61)$.

Sugarcane growth increases were associated with a reduction in root rot severity in organic material-amended soils. However, the effects of amendments with different materials on root colonization by $P$. arrhenomanes were erratic in field soil and steam-treated soil infested with $P$. arrhenomanes. In many cases, disease suppression was not reflected by a decrease in measured Pythium infection. This is in contrast to the effect of treatment with metalaxyl. Isolation of $P$. arrhenomanes from roots of corn plants increased markedly when sampling was done following rain or irrigation (16). P. arrhenomanes also may cause ephemeral infections in sugarcane capable of reducing root system development and plant growth. Another possibility is that root infection is not prevented in organic material-amended soils, but the amount of damage to the root system is somehow reduced. The sites and timing of infection by Pythium were not determined in this study.

In studies where disease suppressiveness of an organic material has been associated with microbial activity $(30,31)$, it has been suggested that diseases caused by Pythium are affected by a type of "general suppression" resulting from the failure of propagules to germinate in the presence of a host due to microbiostasis. Much of the research with Pythium has addressed suppression of damping-off. In the studies reported here, the disease was root rot. The $P$. arrhenomanes inoculum added to steamtreated soil consisted mostly of actively growing mycelium. The type of inoculum in field soil was uncertain, but the results for FS and SFS+Pa were generally similar for the different organic materials, except hardwood bark compost. In this experimental system, prevention of propagule germination by a nonspecific type of microbiostasis would not adequately explain the disease suppression obtained. The evidence suggests some form of antagonism may be involved in suppression of root rot caused by Pythium spp. It was found that hyphae of $P$. aphanidermatum were lysed in container medium amended with cattle manure compost, while water extracts promoted oospore germination (44). However, mycelial growth and sporulation of $P$. arrhenomanes was promoted by filter-sterilized water extracts of the organic materials included in this study (unpublished data).

Sugarcane is typically grown as a monoculture in Louisiana. While $P$. arrhenomanes has been demonstrated to be a causal agent of root rot $(21,32,33,51)$, sugarcane root rot is probably caused by a complex of organisms, some of which would be considered "minor pathogens" (53). In Australia, the problem is referred to as "poor root syndrome" (14). A comparison of the effects of metalaxyl and organic material amendments in nonsterile field soil and steam-treated field soil infested only with $P$. arrhenomanes in this study would support the concept of a complex etiology for sugarcane root rot. The effects of metalaxyl treatment and beneficial amendments on root rot severity and plant growth in nonsterile field soil were similar, or the effects of organic materials were superior. In contrast, metalaxyl treatment was usually superior to organic material amendment in steam-treated soil infested with $P$. arrhenomanes. The poor agreement between root rot suppression and $P$. arrhenomanes colonization also suggests the involvement of other microorganisms. It is likely that the reductions in disease severity and plant growth increases in field soil resulting from organic material amendments were due to suppression of a complex of pathogenic microorganisms.

Biological and chemical properties varied among the seven organic materials included in this study. Groups of materials with similar properties could be distinguished, and these groupings corresponded with the ability to suppress Pythium root rot of sugarcane when used as a soil 
amendment. Materials that were disease suppressive or nonsuppressive were distinguishable, and in some cases, materials that differed in the ability to suppress disease when added to soil in steam-treated form could be separated based on biological and chemical characteristics.

High microbial activity was a common trait of the organic materials that were disease suppressive. Microbial activity level was inversely correlated with disease severity. This finding supports considerable experimental evidence that microbial activity level is an indicator of the potential of an organic material to suppress soilborne diseases, including those caused by Pythium (3,8,11,30). Additional research has suggested that high bacterial (3) or actinomycete populations (58) are associated with suppressiveness to diseases caused by Pythium spp. Two of the organic materials that suppressed root rot primarily when added in nonsterile form, municipal biosolids and filterpress cake, had the highest microbial activity levels and prokaryotic organism populations. The disease suppressive bark composts exhibited high microbial activity levels with lower prokaryote populations.

A rate of FDA hydrolysis above $3.2 \mu \mathrm{g}$ $\min ^{-1} \mathrm{~g}^{-1}$ dry weight was associated with organic materials capable of suppressing $P$. ultimum populations and Pythium root rot of poinsettia (3). The lowest level of FDA hydrolysis for an organic material capable of suppressing sugarcane root rot symptoms and increasing plant growth was 5.2 $\mu \mathrm{g} \min ^{-1} \mathrm{~g}^{-1}$. An activity level of $4.1 \mu \mathrm{g}$ $\min ^{-1} \mathrm{~g}^{-1}$ was found for municipal solid waste compost; however, some properties of this material made it inhibitory to plant growth.

All of the organic materials contained increased levels of organic $\mathrm{C}$ and total $\mathrm{N}$ and elevated levels of nutrients compared with field soil. A group of materials that best suppressed root rot and increased plant growth when added in nonsterile form, filterpress cake, cotton gin trash compost, and biosolids, shared the common chemical properties of high $\mathrm{N}$ level, lower $\mathrm{C}: \mathrm{N}$ ratio, and high levels of extractable nutrients, including $\mathrm{P}, \mathrm{K}, \mathrm{Ca}, \mathrm{Mg}$, and $\mathrm{Mn}$. The bark composts, which were disease suppressive in steam-treated and nonsterile forms, contained lower $\mathrm{N}$ and high levels of $\mathrm{Ca}$ and $\mathrm{S}$ and had the highest $\mathrm{C}: \mathrm{N}$ ratios. The two materials that generally did not suppress disease and reduced plant growth, the municipal solid and yard waste composts, did not form a homogeneous group in terms of chemical properties. Solid waste compost contained elevated levels of plant nutrients, and it had the highest levels of $\mathrm{Fe}$ and $\mathrm{S}$. In addition, it contained the highest levels of salts and $\mathrm{Na}$. The yard waste compost contained lower amounts of $\mathrm{C}$ and $\mathrm{N}$ and elevated but generally lower levels of nutrients compared with the other organic materials.
The nutrients present at highest concentration in the organic materials were generally elevated in amended soil (17). Nutrient levels were determined in tissues of plants grown in soil amended with only four of the materials (17). Biosolids was the only material that elevated nutrient levels, including $\mathrm{N}$, in plant tissues. However, plant growth was not increased in steam-treated soil amended with biosolids.

The relationship of mineral nutrient levels in organic materials capable of suppressing soilborne disease has received less attention. Microbial activity, mineral nutrient availability, and soilborne disease incidence and severity are interrelated (34). Suppression of lettuce drop following amendment of soil with composted municipal sludge was associated with increased soil levels of $\mathrm{N}, \mathrm{P}, \mathrm{Ca}$, and $\mathrm{Mg}$, as well as increased microbial activity (43). The Ca content of soil has been associated with suppressiveness to damping-off caused by Pythium (36) and lysis of Pythium oospores (50). $\mathrm{Mn}$ is another element that can have complex effects on microbial activity and soilborne disease (34). The results of this study indicated that increased levels of $\mathrm{N}, \mathrm{P}, \mathrm{Ca}, \mathrm{Mg}, \mathrm{Mn}$, and $\mathrm{Cu}$ were correlated with microbial activity or community composition and thereby indirectly affected the interactions with pathogens and the host plant that resulted in disease suppression. However, none of the chemical properties assessed were predictive of the potential of an organic material to suppress sugarcane root rot when used as a soil amendment.

Soluble salt levels were generally elevated in organic materials and materialamended soil. However, there were no apparent effects on plant growth or disease suppression, with the probable exception of amendment with municipal solid waste compost. High salt levels may have been associated with the reductions in plant growth that occurred in solid waste compost amended, steam-treated soil. Composted municipal sludge with high salinity has been reported to increase Phytophthora root rot of soybean immediately after soil amendment, whereas application several months before planting resulted in disease suppression $(30,31)$.

In summary, biological and chemical properties could be used to characterize two growth-enhancing groups of organic materials that were most suppressive to sugarcane root rot in nonsterile form or were suppressive in nonsterile and steamtreated forms, and one group that was nonsuppressive and did not increase growth. Chemical properties, such as $\mathrm{N}, \mathrm{P}, \mathrm{K}, \mathrm{Ca}$, and $\mathrm{Mn}$ levels and $\mathrm{C}: \mathrm{N}$ ratio, distinguished materials that may accomplish disease suppression and promote plant growth by different mechanisms. However, chemical properties were not predictive of an organic material's potential to be disease suppressive. As in previous studies, micro- bial activity level was an indicator of the potential of an organic waste to be disease suppressive when used as a soil amendment.

Increases in plant growth resulting from soil amendments with different organic materials have been documented for various crops and attributed to improvements in nutritional and physical soil properties and microbial interactions, including soilborne disease suppression. The present study demonstrated that different organic materials have varied effects on root rot and the growth of sugarcane. The results suggest that soil amendment with some organic materials represents a potential management practice for sugarcane root rot, a disease problem for which effective management practices are currently not available. In addition, they provide evidence supporting the concept that soil amendment with organic materials may provide a sustainable, effective biological disease control option for soilborne plant disease.

\section{ACKNOWLEDGMENTS}

We thank L. Brock and R. Hendrick for providing the biosolids and composts, respectively, L. B. Grelen and S. Bodden for technical assistance, and G. A. Breitenbeck for advice and technical assistance.

\section{LITERATURE CITED}

1. Bevacqua, R. F., and Mellano, V. J. 1994 Cumulative effects of sludge compost on crop yields and soil properties. Commun. Soil Sci. Plant Anal. 25:395-406.

2. Blackburn, F. 1984. Sugar Cane. Longman, Inc., New York.

3. Boehm, M. J., Madden, L. V., and Hoitink, H. A. J. 1993. Effect of organic matter decomposition level on bacterial species diversity and composition in relation to Pythium damping off severity. Appl. Environ. Microbiol. 59:4171-4179.

4. Brock, L. T., Cochran, B. J., and Hoy, J. W. 1995. Municipal bio-solids for sugarcane production. Pages 57-59 in: Proc. Conf. Environ. Issues. H. M. Selim and W. H. Brown, eds. La. State Univ. Agric. Center Publ.

5. Carter, C. E. 1977. Excess water decreases cane and sugar yields. J. Am. Soc. Sugar Cane Technol. 6:44-51.

6. Chef, D. G., Hoitink, H. A. J., and Madden, L. V. 1983. Effects of organic components in container media on suppression of Fusarium wilt of chrysanthemum and flax. Phytopathology 73:279-281.

7. Chen, W., Hoitink, H. A. J., and Schmitthenner, A. F. 1987. Factors affecting suppression of Pythium damping-off in container media amended with composts. Phytopathology 77:755-760.

8. Chen, W., Hoitink, H. A. J., Schmitthenner, A F., and Tuovinen, O. H. 1988. The role of microbial activity in suppression of damping-off caused by Pythium ultimum. Phytopathology 78:314-322.

9. Connell, T. D. 1952. A survey of bacteria antagonistic to Pythium arrhenomanes in Louisiana sugarcane soils. (Abstr.) Phytopathology 42:464.

10. Cooper, W. E., and Chilton, S. J. P. 1950 Studies on antibiotic soil organisms. 1. Actinomycetes antibiotic to Pythium arrhenomanes in sugar-cane soils of Louisiana. Phytopathology 40:544-552. 
11. Craft, C. M., and Nelson, E. B. 1996. Microbial properties of composts that suppress damping-off and root rot of creeping bentgrass caused by Pythium graminicola. Appl. Environ. Microbiol. 62:1550-1557.

12. Crawford, D. L., Lynch, J. M., Whipps, J. M., and Ousley, M. A. 1993. Isolation and characterization of actinomycete antagonists of a fungal root pathogen. Appl. Environ. Microbiol. 59:3899-3905.

13. Cripps, R. W., Winfree, S. K., and Reagan, J. L. 1992. Effects of sewage application method on corn production. Commun. Soil Sci. Plant Anal. 23:1705-1715.

14. Croft, B. J., Reghenzani, J. R., and Hurney, A. P. 1984. Northern poor root syndrome of sugarcane-Studies on soil transmission and the effects of various fungicidal, nutritional and agronomic treatments. Proc. Aust. Soc. Sugar Cane Technol. 6:69-77.

15. Daft, G. C., Poole, H. A., and Hoitink, H. A. J. 1979. Composted hardwood bark: A substitute for steam sterilization and fungicide drenches for control of poinsettia crown and root rot. HortScience 14:185-187.

16. Deep, I. W., and Lipps, P. E. 1996. Recovery of Pythium arrhenomanes and its virulence on corn. Crop Prot. 15:85-90.

17. Dissanayake, N. 1996. Effects of organic waste amendments, herbicides, and weed hosts on Pythium root rot of sugarcane. Ph.D. diss. Louisiana State University, Baton Rouge.

18. Dissanayake, N., Hoy, J. W., and Breitenbeck, G. A. 1994. Effects of soil amendment with organic wastes on Pythium root rot and growth of sugarcane. (Abstr.) Phytopathology $84: 1153$

19. Donohue, S. J. 1992. Reference soil and media diagnostic procedures for the southern region of the United States. Va. Agric. Exp. Stn., South. Coop. Series Bull. 374.

20. Edgerton, C. W. 1939. Stubble deterioration. Proc. Int. Soc. Sugar Cane Technol. 6:334341

21. Edgerton, C. W., Tims, E. C., and Mills, P. J. 1929. Relation of species of Pythium to the root rot disease of sugarcane. Phytopathology 19:549-564

22. Erhart, E., and Burian, K. 1997. Evaluating quality and suppressiveness of Austrian biowaste composts. Compost Sci. Util. 5:15-

23. Fliebbach, A., Martens, R., and Reber, H. H. 1994. Soil microbial biomass and microbial activity in soil treated with heavy metal contaminated sewage sludge. Soil Biol. Biochem. 26:1201-1205

24. Giusquiani, P. L., Marucchini, C., and Businelli, M. 1988. Chemical properties of soil amended with compost of urban waste. Plant Soil 109:73-78.

25. Giusquiani, P. L., Paglia, M., Gigliotti, G., Businelli, D., and Benetti, A. 1995. Urban waste compost: Effects on physical, chemical, and biochemical properties. J. Environ. Qual. 24:175-182.

26. Gugino, J. L., Pokorny, F. A., and Hendrix, F. F., Jr. 1973. Population dynamics of Pythium irregulare Buis. in container-plant production as influenced by physical structure of media. Plant Soil 39:591-602.

27. Hadar, Y., and Mandelbaum, R. 1986. Suppression of Pythium aphanidermatum damping-off in container media containing liquo- rice roots. Crop Prot. 5:88-92.

28. Hallmark, W. B., Feagley, S. E., Breitenbeck, G. A., Brown, L. P., Wan, X., and Hawkins, G. L. 1994. Influence of composted municipal waste on sugarcane yields and fertilizer requirements. Pages 164-167 in: Sugarcane Res. Annu. Prog. Rep. 1993. La. Agric. Exp. Stn. Publ.

29. Hoitink, H. A. J. 1980. Composted bark, a lightweight growth medium with fungicidal properties. Plant Dis. 64:142-147.

30. Hoitink, H. A. J., Boehm, M. J., and Hadar, Y 1993. Mechanisms of suppression of soilborne plant pathogens in compost-amended substrates. Pages 601-621 in: Science and Engineering of Composting: Design, Environmental, Microbiological and Utilization Aspects. H. A. J. Hoitink and H. M. Keener, eds. Renaissance Publishing, Worthington, $\mathrm{OH}$.

31. Hoitink, H. A. J., and Fahy, P. C. 1986. Basis for the control of soilborne plant pathogens with composts. Annu. Rev. Phytopathol. 24:93-114.

32. Hoy, J. W., and Schneider, R. W. 1988. Role of Pythium in sugarcane stubble decline: Pathogenicity and virulence of Pythium species. Phytopathology 78:1688-1692.

33. Hoy, J. W., and Schneider, R. W. 1988. Role of Pythium in sugarcane stubble decline: Effects on plant growth in field soil. Phytopathology 78:1692-1696.

34. Huber, D. M., and Wilhelm, N. S. 1998. The role of manganese in resistance to plant disease. Pages 155-173 in: Manganese in Soils and Plants. R. D. Graham, R. J. Hannam, and N. C. Uren, eds. Kluwer Academic Publishers, Cordrecht, Netherlands.

35. Johnson, L. F. 1954. Antibiosis in relation to Pythium root rot of sugarcane and corn. Phytopathology 44:69-73.

36. Kao, C. W., and Ko, W. H. 1986. The role of calcium and microorganisms in suppression of cucumber damping-off caused by Pythium splendens in a Hawaiian soil. Phytopathology 76:221-225.

37. Koike, H. 1967. Methods for testing sugarcane for resistance to Pythium root rot. Proc. Int. Soc. Sugar Cane Technol. 12:1183-1187.

38. Leal, J. F. 1989. Application of filter mud to sugarcane soils. Proc. Inter-Am. Sugar Cane Seminar 1989:456-463

39. Lewis, J. A., Lumsden, R. D., Millner, P. D., and Keinath, A. P. 1992. Suppression of damping-off of peas and cotton in the field with composted sewage sludge. Crop Prot. 11:260-266.

40. Lindsay, W. L., and Norvell, W. A. 1978. Development of a DPTA soil test for zinc, iron, manganese, and copper. Soil Sci. Soc. Am. J. 42:421-428.

41. Luke, H. H. 1952. Fungi isolated from sugarcane soils of Louisiana and their antagonistic effects on Pythium arrhenomanes. (Abstr.) Phytopathology 42:469.

42. Lumsden, R. D., Lewis, J. A., and Millner, P. D. 1983. Effect of composted sewage sludge on several soilborne pathogens and diseases. Phytopathology 73:1543-1548.

43. Lumsden, R. D., Millner, P. D., and Lewis, J. A. 1986. Suppression of lettuce drop caused by Sclerotinia minor with composted sewage sludge. Plant Dis. 70:197-201.

44. Mandelbaum, R., Borodecki, M., and Hadar, Y. 1985. The use of composts for production of disease-suppressive container media (Abstr.) Phytoparasitica 13:158.

45. Martin, J. K. 1975. Medium for enumeration of total bacteria from soil samples. Soil Biol. Biochem. 7:401-402.

46. Mays, D. A., and Giordano, P. M. 1988. Benefits from land application of municipal sewage sludge. Circ. Z-238. Tennessee Valley Authority, National Fertilizer Development Center, Muscle Shoals, AL

47. Mircetich, S. M., and Matheron, M. E. 1976. Phytophthora root and crown rot of cherry trees. Phytopathology 66:549-558.

48. Nelson, E. B., Craft, C. M., and Feldman, K. A. 1993. Suppression of Pythium graminicola root rot and damping-off of creeping bentgrass with composts of different origins and levels of maturity. (Abstr.) Phytopathology $83: 1366$.

49. Nelson, E. B., and Hoitink, H. A. J. 1983. The role of microorganisms in the suppression of Rhizoctonia solani in container media amended with composted hardwood bark. Phytopathology 73:274-278.

50. Qian, P., and Johnson, L. F. 1987. Chemical and physical soil characteristics related to lysis of oospores of Pythium ultimum. Phytopathology 77:1062-1066.

51. Rands, R. D., and Dopp, E. 1938. Pythium rot of sugarcane. U.S. Dep. Agric. Tech. Bull 666.

52. Reghenzani, J. R. 1988. Northern sugarcane response to soil solarization. Proc. Aust. Soc Sugar Cane Technol. 10:163-169.

53. Salt, G. A. 1979. The increasing interest in "minor pathogens". Pages 289-312 in: Soilborne Plant Pathogens. B. Schippers and W. Gams, eds. Academic Press, New York.

54. Schnurer, J., and Rosswall, T. 1982. Fluorescein diacetate hydrolysis as a measure of total microbial activity in soil and litter. Appl. Environ. Microbiol. 43:1256-1261.

55. Srinivasan, K. V. 1968. The role of the rhizosphere microflora in the resistance of sugarcane to Pythium root rot. Proc. Int. Soc. Sugar Cane Technol. 13:1224-1236.

56. Srinivasan, K. V., and Narasimhan, R. 1963. Evolving varieties for resistance to Pythium root rot. Int. J. Sugarcane Res. Dev. 7:273 275.

57. Stephens, C. T., and Stebbins, T. C. 1985 Control of damping-off pathogens in soilless container media. Plant Dis. 69:494-496.

58. Stockwell, C. A., Nelson, E. B., and Craft, C. M. 1994. Biological control of Pythium graminicola and other soilborne pathogens of turfgrass with actinomycetes from composts. (Abstr.) Phytopathology 84:1113.

59. Theodore, M., and Toribio, J. A. 1995. Suppression of Pythium aphanidermatum in composts prepared from sugarcane factory residues. Plant Soil 177:219-233.

60. Trillas-Gay, M. I., Hoitink, H. A. J., and Madden, L. V. 1986. Nature of suppression of Fusarium wilt of radish in a container medium amended with composted hardwood bark. Plant Dis. 70:1023-1027.

61. Turner, M. S., Clark, G. A., Stanley, C. D., and Smajstrla, A. G. 1994. Physical characeristics of a sandy soil amended with municipal solid waste compost. Proc. Soil Crop Sci. Fla. 53:24-26.

62. Van der Plaats-Niterink, A. J. 1981. Monograph of the genus Pythium. Stud. Mycol. 21:1-242 